\title{
Renewable energy and water sustainability: lessons learnt from TUISR19
}

\author{
Alaa A. Masoud ${ }^{1}$ \\ Published online: 26 March 2020 \\ (C) Springer-Verlag GmbH Germany, part of Springer Nature 2020
}

\section{Introduction}

Economic growth and social development are driven by energy and water. The sustainability of both resources became a must in order to achieve development synergies to overcome the challenges of climate change and food security which are exacerbated by population growth and urbanization which create a dynamic baseline against which to address service access. Efficiency of energy and the effective deployment of renewable energy resources along with mitigation of water pollution can reduce costs of energy and water provision, increase access to services, and reduce greenhouse gas emissions and hence lessen environmental impacts on economy and public health. Therefore, TUISR 19 topics have met the national needs for facing the challenges arising from resource scarcity, variability, and uncertainty driven by changes brought on by population growth, and the opportunities driven by recent technological advances and policy developments. The event addressed many issues that contribute to the implementation of strategies, and promote and disseminate knowledge about the various integrated and intelligent technologies for the safe, secure, sustainable, and affordable renewable energy and water resources. Adding to that, the most suitable and effective ways to design, finance, and build better and more sustainable resources with a common vision to identify threats, risks, and key opportunities to drive future investments in both renewable energy and water resources have been explored in the proceedings of the TUISR 19 successful event. Nine topics were discussed and research results were presented in a compelling manner on novel technologies and applications of the renewable energy and water systems

Responsible Editor: Philippe Garrigues

Alaa A. Masoud

alaa_masoud@science.tanta.edu.eg

1 Remote Sensing Laboratory, Geology Department, Faculty of Science, Tanta University, Tanta 31527, Egypt covering issues of (1) technologies of renewable energy and energy storage; (2) new materials for energy applications; (3) water management and crop composition; (4) water treatment and desalination; (5) media: energy and water issues; (6) environmental hazards and therapeutic uses; (7) legal challenges and economic concepts; (8) future trends in energy, water sustainability, and climate; and (9) remote sensing techniques and GIS applications.

This special issue cannot fully reflect the diversity and creativity of the ideas and new insights that were shared at TUISR19. However, as editor of this special issue and member of the scientific committee of the event, I hope that this issue may prompt scientists from the diverse fields to participate in the upcoming conferences at Tanta University to come: the collected papers show and justify the strong position of the adopted techniques in worldwide studies to help solve problems related to the renewable energy sources and water sustainability.

\section{Results and discussion}

\section{Renewable energy sustainability}

For renewable energy productivity enhancement, several articles addressed the importance of the solar still geometry and heat transfer fluids in multi-cavity solar receivers (Duraisamy Ramalingam et al. 2019), use of water film cooling and hybrid composite insulation (Balachandran et al. 2019a), use of thermally conductive nano-ferric oxide (Balachandran et al. 2019b), and the optimal sizing of hybrid solar/wind/hydroelectric pumped storage energy system based on different meta-heuristic techniques (Diab et al. 2019). The professional use of cement-coated red bricks for augmenting the production of distilled water using a traditional single slope solar still by low-cost energy storage was investigated in Kabeel et al. (2019). Three different designs of a hybrid PV/T double-pass finned plate solar air heater have been evaluated in Hegazy 
et al. (2020). Mathematical model that was experimentally validated for square pyramid solar still has been addressed in El-Sebaii and Khallaf (2020). Madhu et al. (2020) investigated the experimental enhancement of heat transfer through conventional and staggered fin solar air heater coated with CNTblack paint. For diesel engine exhaust emission control, Solomon et al. (2019) addressed the development of electrochemical cells based on the electrochemical decomposition of $\mathrm{NO}_{\mathrm{x}}$ and oxidation of $\mathrm{HC}$ and $\mathrm{CO}$ emissions.

At varying flow rates of air and water, Duraisamy Ramalingam et al. (2019) studied the inferences on the effects of geometries and heat transfer fluids in multi-cavity solar receivers. Results revealed that receivers made up of $\mathrm{SiC}$ material proved superior in thermal performance to that made of aluminum and copper. The heat transfer fluids of air and water achieved the maximum energy efficiency of $21.11 \%$ and $75.81 \%$, at flow rate of $1.351 / \mathrm{min}$ and $0.91 / \mathrm{min}$, respectively. Balachandran et al. (2019a) addressed the productivity enhancement of PV/T-integrated single slope solar desalination still using water film cooling and hybrid composite insulation. Results clarified the increase of $35 \%$ and $21 \%$ in the amount of distilled water by using water film cooling over glass cover and HNFC insulation at $0.5-\mathrm{cm}$ and $1-\mathrm{cm}$ depths, yielding 2.253 and $1.420 \mathrm{l} / \mathrm{m}^{2} /$ day, respectively, when compared with the conventional type SSSDS with polystyreneStyrofoam (thermocol) insulation.

In order to fetch new technologies to resolve water scarcity by desalination of saline water, Balachandran et al. (2019b) investigated the efficiency of single-sloped solar still using thermally conductive nano-ferric oxide. The cumulative yield for nano absorbent layer solar still $\left(4.39 \mathrm{~kg} / \mathrm{m}^{2}\right)$ proved superior to that for the micro absorbent layer solar still $(3.23 \mathrm{~kg} /$ $\mathrm{m}^{2}$ ).

In order to minimize the cost of energy from the hybrid system while satisfying the operation constraints including high reliability of the hybrid power supply, small fluctuation in the energy injected to the grid, and high utilization of the photovoltaic and wind complementary properties, Diab et al. (2019) addressed the potentiality of the optimal sizing of hybrid solar/wind/hydroelectric pumped storage energy system based on different meta-heuristic techniques. Hegazy et al. (2020) studied three different designs of a hybrid PV/T double-pass finned plate solar air heater (DPFPSAH). The $\mathrm{PV}$ module is used to produce electricity needed to run the pump and blow the air into the solar collector. The third design of the hybrid systems where the PV module is completely separated from the solar collector has the highest overall performance. The daily thermal efficiencies of the first, second, and third designs of the hybrid systems are obtained as $53 \%$, $27 \%$, and $64 \%$, respectively, at mass flow rate of $0.02 \mathrm{~kg} / \mathrm{s}$. ElSebaii and Khallaf (2020) presented a mathematical model that was experimentally validated for square pyramid solar still where the daily productivity of the pyramid solar still
$\left(P_{\mathrm{d}}\right)$ varied from 4.22 to $4.43 \mathrm{~kg} / \mathrm{m}^{2}$ day with values of the glass cover's tilt angle of $10-60^{\circ}$. Values of the top losses of the still decreased from 8.8064 to $8.2304 \mathrm{~W} / \mathrm{m}^{2} \mathrm{~K}$ with increasing glass cover surface area from 0.063 to $0.125 \mathrm{~m}^{2}$, which correspond to values of tilt angles of the still covers changing from 10 to $60^{\circ}$, respectively. Kabeel et al. (2019) addressed the professional use of cement-coated red bricks for augmenting the production of distilled water using a traditional single slope solar still by low-cost energy storage. They stated the improvement of about $34 \%$ in the temperature of water which acts as the driving force for evaporation and hence the productivity was enhanced by $45 \%$ as compared to the conventional solar still. $\mathrm{NO}_{\mathrm{x}}$ emission has a serious effect on the environment, and it has to be controlled effectively. Madhu et al. (2020) investigated the experimental enhancement of heat transfer through conventional and staggered fin solar air heater coated with CNT-black paint. Results revealed that the effect of coating improved the plate temperature to a maximum of $102{ }^{\circ} \mathrm{C}$ while the modified solar air heater $(\mathrm{SAH})$ coated with ordinary black paint and staggered fin arrangement is found as $95^{\circ} \mathrm{C}$ for the flow rate of $m_{\mathrm{f}}=$ $0.03 \mathrm{~kg} / \mathrm{s}$.

For diesel engine exhaust emission control, Solomon et al. (2019) addressed the development of electrochemical cells based on the electrochemical decomposition of $\mathrm{NO}_{\mathrm{x}}$ and oxidation of $\mathrm{HC}$ and $\mathrm{CO}$ emissions. The developed cells operated at low power with reduced complexity works efficiently in the oxygen-rich diesel exhaust proved high $\mathrm{NO}_{\mathrm{x}}$ decomposition rate of $80 \%$ at the exhaust temperatures between 350 and $400{ }^{\circ} \mathrm{C}$. The $\mathrm{HC}$ reduction has reached up to $65 \%$ and $\mathrm{CO}$ reduction has been acheived up to $45 \%$.

\section{Water sustainability}

For addressing stresses on water resources sustainability management, water quality parameters of lake water induced by climate change (Shalaby et al. 2019), rainwater harvesting (Gado and El-Agha 2019), and drainage water salinity and quality (El-Agha et al. 2019). Gemeay et al. 2019 addressed the feasibility of removal of four commercial reactive wool dyes from industrial wastewaters, hence decreasing the potential hazardous of nanomaterial to the environment.

Shalaby et al. (2019) investigated the impacts of future climate change (CC) on water quality parameters of Lake Burullus monitored at twelve stations throughout the lagoon. The results showed that $\mathrm{CC}$ has the potential to radically alter the physical and chemical structure of Lake Burullus as it is expected to be warmer and more saline. The risk of oxygen depletion was firmly predictable with significant spatial differences of DO decreasing. A prolonged residence time is expected, accompanied by an increasing trend of phosphate and chlorophyll $a$ and a decreasing trend of nitrate. Gado and El-Agha (2019) demonstrated that the implementation of 
rainwater harvesting-RWH system has a significant impact on the regional water cycle, where the effective infiltration coefficient increased from $10 \%$ (No-RWH) to $75 \%$ (RWH) in the case study. Accordingly, the runoff coefficient decreased from 0.8 (No-RWH) to 0.15 (RWH), and the volume of runoff decreased by around $82 \%$ than that of the No-RWH condition. Thus, direct infiltration of RWH into an aquifer can play an important role in sound water management for urban environments, as this may lead to a significant reduction in risks of flooding and expenses of municipal drainage systems installation and operation. Drainage water quality variation in space and time has been addressed in El-Agha et al. (2019). Gemeay et al. 2019 addressed the feasibility of removal of four commercial reactive wool dyes from industrial wastewaters, hence decreasing the potential hazardous of nanomaterial to the environment.

\section{Environmental health issue}

In terms of the environmental health consequences impacted by natural factors such as work stresses, Hassan et al. (2020) investigated the effects from prolonged working hours, sleep deprivation, and high job demands on 278 physicians at Tanta University Hospitals between December 2016 and February 2017. Medical residents experienced moderate to high level of job stress resulted from the underpayment for the job (87.4\%), serving to large number of patients $(85.2 \%)$, disruption of home life due to long hours at work (83.9\%), conflict of responsibilities (81.3), and complying with increasing bureaucratic procedures $(78.8 \%$ ) besides no available fund for research (74.8\%). Abd-Elkader et al. (2020) highlighted the increasingly alarming phenomenon of tramadol abuse among the Egyptian Community. A total of 900 persons, 300 males chosen randomly from three groups; minibus drivers, construction, and textile industries workers were crosssectionally studied. Tramadol intake was high at $92.3 \%$ among the construction workers followed by $53.0 \%$ among the bus drivers, and lastly $25.3 \%$ among the textile workers. Friends of $45.4 \%$ and drug dealers $16.6 \%$ are the main source of tramadol. Mood improvement (54.3\%), pain relief, and help to continue work (37.3\%) are the main reasons of abuse.

Acknowledgments The author express his deepest gratitude to Professor Philippe Garrigues, Editor-in-Chief of the Environmental Science and Pollution Research, and for the anonymous reviewers of the selected articles for their valuable time and effort as well as for their constructive comments which improved the rigor and the quality of the articles and the special issue in whole.

\section{References}

Abd-Elkader MR, Kabbash IA, El-Sallamy RM et al (2020) Tramadol abuse among workers in an industrial city in mid-Nile Delta region,
Egypt. Environ Sci Pollut Res:1-8. https://doi.org/10.1007/s11356020-08040-8

Balachandran GB, David PW, Mariappan RK, Kabeel AE, Athikesavan MM, Sathyamurthy R (2019a) Improvising the efficiency of singlesloped solar still using thermally conductive nano-ferric oxide. Environ Sci Pollut Res:1-14. https://doi.org/10.1007/s11356-01906661-2

Balachandran GB, David PW, Vijayakumar ABP, Kabeel AE, Athikesavan MM, Sathyamurthy R (2019b) Enhancement of PV/ T-integrated single slope solar desalination still productivity using water film cooling and hybrid composite insulation. Environ Sci Pollut Res:1-12. https://doi.org/10.1007/s11356-019-06131-9

Diab AAZ, Sultan HM, Kuznetsov ON (2019) Optimal sizing of hybrid solar/wind/hydroelectric pumped storage energy system in Egypt based on different meta-heuristic techniques. Environ Sci Pollut Res:1-23. https://doi.org/10.1007/s11356-019-06566-0

Duraisamy Ramalingam R, Esakkimuthu GS, Paulraj J, Abd Elnaby K, Athikesavan M, Sathyamurthy R, Vaithilingam S (2019) Inferences on the effects of geometries and heat transfer fluids in multi-cavity solar receivers by using CFD. Environ Sci Pollut Res:1-13. https:// doi.org/10.1007/s11356-019-06829-w

El-Agha DE, Molle F, Rap E et al (2019) Drainage water salinity and quality across nested scales in the Nile Delta of Egypt. Environ Sci Pollut Res:1-12. https://doi.org/10.1007/s11356-019-07154-y

El-Sebaii A, Khallaf AE (2020) Mathematical modeling and experimental validation for square pyramid solar still. Environ Sci Pollut Res: 1-13. https://doi.org/10.1007/s11356-019-07587-5

Gado T, El-Agha D (2019) Feasibility of rainwater harvesting for sustainable water management in urban areas of Egypt. Environ Sci Pollut Res:1-14. https://doi.org/10.1007/s11356-019-06529-5

Gemeay AH, Keshta BE, El-Sharkawy RG et al (2019) Chemical insight into the adsorption of reactive wool dyes onto amine-functionalized magnetite/silica core-shell from industrial wastewaters. Environ Sci Pollut Res:1-18. https://doi.org/10.1007/s11356-019-06530-y

Hassan NM, Abu-Elenin MM, Elsallamy RM, Kabbash IA (2020) Job stress among resident physicians in Tanta University hospitals, Egypt. Environ Sci Pollut Res:1-8. https://doi.org/10.1007/ s11356-020-08271-9

Hegazy MM, El-Sebaii A, Ramadan MR et al (2020) Comparative study of three different designs of a hybrid PV/T double-pass finned plate solar air heater. Environ Sci Pollut Res:1-13. https://doi.org/10. 1007/s11356-019-07487-8

Kabeel AE, El-Agouz E, Athikesavan MM et al (2019) Comparative analysis on freshwater yield from conventional basin-type single slope solar still with cement-coated red bricks: an experimental approach. Environ Sci Pollut Res:1-11. https://doi.org/10.1007/ s11356-019-07288-Z

Madhu B, Kabeel AE, Sathyamurthy R, Sharshir SW, Manokar AM, Raghavendran PR, Chandrashekar T, Mageshbabu D (2020) Investigation on heat transfer enhancement of conventional and staggered fin solar air heater coated with CNT-black paint - an experimental approach. Environ Sci Pollut Res:1-19. https://doi.org/ 10.1007/s11356-019-07561-1

Shalaby A, Elshemy M, Zeidan BA (2019) Assessment of climate change impacts on water quality parameters of Lake Burullus, Egypt. Environ Sci Pollut Res:1-22. https://doi.org/10.1007/s11356-01906105-X

Solomon JM, Pachamuthu S, Arulanandan JJ, Thangavel N, Sathyamurthy R (2019) Electrochemical decomposition of Nox and oxidation of $\mathrm{HC}$ and $\mathrm{CO}$ emissions by developing electrochemical cells for diesel engine emission control. Environ Sci Pollut Res: 1-10. https://doi.org/10.1007/s11356-019-07327-9

Publisher's note Springer Nature remains neutral with regard to jurisdictional claims in published maps and institutional affiliations. 


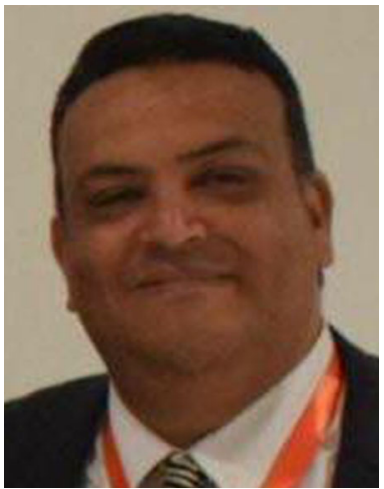

Professor Alaa A. Masoud is the director of the Remote Sensing Laboratory at the Geology Department, Faculty of Science, Tanta University (Egypt). He is an associate of COSPARCommittee on Space Research, (France). Professor Masoud is a member of the National Committee of Astronomy \& Space Sciences at the Ministry of Higher Education and a member of Space \& Remote Sensing Council at the Academy of Scientific Research and Technology - ASRT (Egypt). Current research activities are oriented on the designing and the implementation of decision support systems as well as software development in the field of environmental geology and remote sensing (RS), especially water and soil resources management projects, along with renewable energy potential modeling from algae/ agricultural waste biomass, as well as from wave, solar, and wind utilizing Sentinel 2 and 3 RS imageries. 